\title{
TOP3A wt Allele
}

National Cancer Institute

\section{Source}

National Cancer Institute. TOP3A wt Allele. NCI Thesaurus. Code C50385.

Human TOP3A wild-type allele is located within 17p12-p11.2 and is approximately $41 \mathrm{~kb}$ in length. This allele, which encodes DNA topoisomerase 3-alpha protein, is involved in the ATP-independent breakage of neg atively supercoiled single-stranded DNA and subsequent passage/rejoining of the broken DNA. 